\title{
Screening of Anticancer Materials from Myxobacteria in Different Natural Ecological Environment
}

\author{
Zhang Liping (Corresponding Author) \\ Key Lab of Microbial Diversity Research and Application of Hebei Province \\ College of Life Sciences, Hebei University \\ Baoding 071002, Hebei Province, China \\ Jia Hong \\ Key Lab of Microbial Diversity Research and Application of Hebei Province \\ College of Life Sciences, Hebei University \\ Baoding 071002, Hebei Province, China
}

Received: January 1, 2011 Accepted: January 17, 2011 doi:10.5539/ijb.v3n2p57

This research was financially supported by Hebei Province Research Project titled "Hebei microbial resource base information database" (Grant No. 10967146D).

\begin{abstract}
By study on ecological diversity of myxobacteria in some areas of Hebei, Yunnan Province and the Qinghai-Tibet Plateau, more than 150 strains of 10 genera (Archangium, Myxococcus, Cystobacter, Corallococcus, Melittangium, Sorangium, Polyangium, Chondromyces, Angiococcus and Stigmatella) of Myxococcales were isolated from 42 samples, including some special strains that have never been described before. The isolated strains were preliminary identified at generic level by fruiting bodies, swarms, myxospores and vegetative cells. Myxobacteria strains that were preserved by the Key Lab of Microbial Diversity Research and Application of Hebei Province were used to screen anticancer drugs by MTT high throughout method, with tumor cell lines such as L1210, Hela and MRC-5 as screening model. The result demonstrated that most of the strains could inhibit growth of tumor cells. The inhibition rates were about 78.5\% to L1210 cell line, about 59\% to Hela cell line. Strain 910018 and 920036 showed higher bioactivity for growth inhibition of L1210 and Hela cell lines, while showed lower bioactivity to MRC-5 cell line. Therefore, both of strains are valued for in vivo tumor inhibition experiments.
\end{abstract}

Keywords: Myxobacteria, MTT, Tumor-inhibited rate, L1210, Hela

\section{Introduction}

Myxobacteria are a class of Gram-negative prokaryotes with complex multi-cellular behavior and morphology (Fang \& Zhang, 2001). According to the phylogenetic analysis based on 16S rDNA sequences, Myxobacteria belong to $\delta$ - subclass of Proteobacteria (Iizuka et al., 2003). In the second edition of "Bergey's Manual of Systematic Bacteriology", Myxobacteria are classified as Myxococcales of Deltaproteobacteria of Proteobacter and include 3 orders, 6 families, 19 genus and 62 species (George et al., 2004). In order to protect Myxobacteria biodiversity and exploit potential strains, regional distribution of diversity was investigated in this study. More than 150 strains of 10 genera (Archangium, Myxococcus, Cystobacter, Corallococcus, Melittangium, Sorangium, Polyangium, Chondromyces, Angiococcus and Stigmatella) of Myxococcales were isolated from 42 samples, which were collected from different areas in Hebei, Yunnan Province and the Qinghai-Tibet Plateau. The distribution information was demonstrated in Table 1.

\section{Methods and Materials}

\subsection{Materials}

\subsubsection{Strains}

All of the strains used in this study were isolated and stored by Key Lab of Microbial Diversity Research and 
Application of Hebei Province.

\subsubsection{Seed medium}

CAS medium: $1 \%$ Casein, $0.1 \% \mathrm{MgSO}_{4} \cdot 7 \mathrm{H}_{2} \mathrm{O}$, adjust to $\mathrm{pH} 7.2$.

2.1.3 Fermentation medium

VY/2 medium: $1 \%$ Yeast powder, $0.1 \% \mathrm{CaCl}_{2} \cdot 2 \mathrm{H}_{2} \mathrm{O}, 0.5 \mathrm{mg} / \mathrm{mL} \mathrm{VB}_{12}$, adjust to $\mathrm{pH} 7.2$.

\subsubsection{Cell medium}

$10 \%$ bovine serum, $90 \%$ RPMI 1640

\subsubsection{Cell lines}

L1210, Hela and MRC-5 were murine leukemia cell lines, human cervical cancer cell lines and Normal diploid human embryonic lung fibroblasts, respectively. L1210 and MRC-5 were supplied by Animal Experimental Center of Hebei Medical University. Hela was supplied by Microbiology lab of Hebei Medical University.

\subsubsection{Extraction of fermentation products}

The Myxobacteria cultures were mixed with same volume of ethanol and incubated overnight. Then the leaching liquor was concentrated with rotary evaporator and the concentrated solution was lyophilized at $-50{ }^{\circ} \mathrm{C}$.

\subsection{Methods}

\subsubsection{Fermentation of Myxobacteria}

Purified strains were remained in VY/2 medium and inoculated to CAS seed medium, shaking with $200 \mathrm{r} / \mathrm{min}$ for 4 days at $28{ }^{\circ} \mathrm{C}$. Then the seed solution was inoculated to fermentation medium VY/2 with ratio of $10 \%$, shacking with $200 \mathrm{rpm} / \mathrm{min}$ for 7 days at $28^{\circ} \mathrm{C}$.

\subsubsection{Screening of anticancer extract from Myxobacteria in vitro by MTT}

\subsubsection{Preparation of sample solution}

Two hundred ml Myxobacteria cultures were extracted by ethanol, concentrated, lyophilized and weighted. Then $4 \mathrm{ml}$ RPMI-1640 medium was used to dissolve the dry sample. The samples were marked with No.

\subsubsection{MTT experiment}

The experiment included 4 dose groups $(3.33 \mathrm{mg} / \mathrm{ml}, 6.65 \mathrm{mg} / \mathrm{ml}, 13.3 \mathrm{mg} / \mathrm{ml}, 26.6 \mathrm{mg} / \mathrm{ml})$ and the culture with same cell density was used as blank control. Solvent control was zero adjustment. $0.1 \mathrm{ml}$ volumes of $10^{5} \mathrm{cfu} / \mathrm{ml}$ cell cultures were added to each well of 96-well plate and the plate was incubated for $12 \mathrm{~h}$. Then, $20 \mu \mathrm{l}$ sample solution was added to each well with triplicate and incubated for $48 \mathrm{~h}$ at $37{ }^{\circ} \mathrm{C}$ with $5 \% \mathrm{CO}_{2}$ saturation. $20 \mu \mathrm{l}$ MTT was added to each well and incubated for $4 \mathrm{~h}$, centrifuged for $10 \mathrm{~min}$ with $2000 \mathrm{rpm} / \mathrm{min}$. Then the supernatant was discarded (should be careful, remain the Formazan particles). $150 \mu$ DMSO was added to each well with shaking for 5-10 min until blue particles were soluble completely and the solution color became dark blue. The $\mathrm{OD}_{570 \mathrm{~nm}}$ was measured immediately and the inhibition rate (IR) of cancer cell proliferation was calculated $(\mathrm{Li}, 2004)$. Then half inhibitory concentration $\left(\mathrm{IC}_{50}\right)$ was calculated by modified Karber method $(\mathrm{Mu}$, 2007).

$$
\begin{array}{r}
\operatorname{IR}(\%)=\left(1-\mathrm{OD}_{570 \mathrm{~nm}} \text { of experiment group/ } \mathrm{OD}_{570 \mathrm{~nm}} \text { of negative control }\right) \times 100 \% \\
\mathrm{IC}_{50}=\lg ^{-1}\left[\mathrm{Xm}-\mathrm{I} \times\left(\mathrm{P}-\frac{3-\mathrm{Pm}-\mathrm{Pn}}{4}\right)\right]
\end{array}
$$

Xm: logarithm of maximum dose; I: difference of the two adjacent logarithmic dose; P: sum of positive reaction rate; Pm: maximum inhibition rate; Pn: minimum inhibition rate

\subsubsection{Data statistical analysis}

The experiment was carried out with six groups and 3 replicates. Data were analyzed by SPSS16.0, using ANOVA and t-test. Test level $\alpha=0.05$ and $\mathrm{P}<0.05$ means significant difference.

\section{Results and discussion}

\subsection{MTT results}

3.1.1 In vitro effect of extract on L1210 and Hela

Forty-eight Myxobacteria strains isolated and stored by Key Lab of Microbial Diversity Research and 
Application of Hebei Province were fermented and extracted. Anticancer materials were screened by MTT method using 96-well plate, with L1210, Hela and MRC-5 cell lines as screening models. The results were showed in Table 2.

Most of the 48 samples could inhibit growth of L1210 and Hela cells. L1210 cells were more sensitive to the extracts than Hela cells. The inhibition activities at dose of $26.6 \mathrm{mg} / \mathrm{mL}$ of 7 strains to L1210 and Hela cells are more than $\mathrm{IC}_{50}$ of $85 \%$ strains (Table 3 ).

The results demonstrated that the secondary metabolite of the 48 Myxobacteria strains could widely inhibit growth of cancer cells. The $\mathrm{IC}_{50}$ of $78.5 \%$ of strains to $\mathrm{L} 1210$ amounts to the bioactive materials in $2 \sim 8 \mathrm{ml}$ original fermentation broth. The $\mathrm{IC}_{50}$ of $59 \%$ of strains to Hela amounts to this value. The inhibition rates of most strain to L1210 were usually higher than that to Hela at the same doses. This demonstrated that L1210 was more sensitive and the inhibition activity of a sample was different to different cancer cells.

\subsubsection{Effect of extracts with different concentration on relative survival of MRC-5}

A good anticancer drug not only could kill cancer cell powerfully, but also minimize the damage to normal cells. Therefore, the sample should be screened by the Normal diploid cells. Fifteen out of 19 strains could inhibit growth of MRC-5 at dose of $20 \mu \mathrm{l}$ /well. No. 7, 20, 5, and 1 samples affected growth of MRC-5 least. The cells remain normal shape and transparent. In addition, No. 7 (extracted from strain 910018) and 20 (extracted from strain 920036) strains could inhibit growth of both L1210 and Hela cells powerfully.

\section{Conclusion}

The secondary metabolites of Myxobacteria have great potentials for application (Guo, 2007; Guo et al., 2007). In the present study, 48 strains isolated and stored by Key Lab of Microbial Diversity Research and Application of Hebei Province were fermented, extracted, concentrated and lyophilized (Guo et al., 2008). The samples were screened by MTT method with 3 cancer cell lines as models (Cheng et al., 2009). Two strains (910018 and 920036), that could inhibit cancer cells but less or not inhibit normal diploid human embryonic lung fibroblasts, could be as candidates of anticancer drugs. However, the function mechanisms still remained to study.

\section{References}

Cheng, F.Q., Zhang, L.P. \& Zhang, H. (2009). Screening of bioactive products from myxobacteria. Journal of Agricultural University Of Hebei, 32 (3), 43-45.

Fang,X.M. \& Zhang, L.P. (2001). A preliminary study on ecological diversity of myxobacteria. Biodiversity Science, 9(3), 207-213.

George, M., Garrity, Julia, A.B. \& Timothy, G.L. (2004). Taxonomic Outline of the Prokaryotes Bergey's Manual of Systematic Bacteriology. 2nd ed. New York: Springer-Verlag, pp134- 137.

Guo, W.J. (2007). Screening of myxobacteria and new antitumor antibiotic produced by myxobacteria. Wuxi, Jiangnan University.

Guo, W.J., Cui, F.J. \& Y., W. (2008). Bioassay-based screening of myxobacteria producing antitumor secondary metabolites. African Journal of Biotechnology, 7, 842-847.

Guo, W.J., Zhu, Q.J. \& Tao, W.Y. (2007). Selection of Polyangium vitellinum JSW103 (Myxobacteria)with High Active Anti-tumor Materials. Guizhou Agricultural Sciences, 35 (2), 5-8.

Iizuka, T., Jojima, Y. \& Fudou R et al. (2003). Enhygromyxa salina gen. nov.,sp. nov., a slightly halophilic myxobacterium isolated from the coastal areas of Japan. System Appl Microbiol, 6, 189-196.

Li, N. (2004). Preliminary study of screening and function mechanisms anticancer of bioactive materials from myxobacteria. Baoding, Hebei University.

$\mathrm{Mu}$, N. (2007). Study of anticancer effect in vivo and function mechanisms of Paradise Rain injection. Shijiazhuang, Hebei Medical University. 
Table 1. Distribution of species in different sites

\begin{tabular}{|c|c|c|c|c|c|c|c|c|c|}
\hline $\begin{array}{c}\text { Sample } \\
\text { source }\end{array}$ & $\begin{array}{c}\text { No.of } \\
\text { sampl } \\
\text { es }\end{array}$ & $\begin{array}{c}\text { Genus } \\
\text { number } \\
\text { isolated }\end{array}$ & $\begin{array}{c}\text { Strain } \\
\text { numb } \\
\text { er } \\
\text { isolat } \\
\text { ed }\end{array}$ & $\begin{array}{c}\text { Average } \\
\text { genus } \\
\text { number } \\
\text { from } \\
\text { each } \\
\text { sample }\end{array}$ & $\begin{array}{c}\text { Averag } \\
\text { e strain } \\
\text { number } \\
\text { from } \\
\text { each } \\
\text { sample }\end{array}$ & $\begin{array}{c}\text { Strain } \\
\text { number } \\
\text { of } \\
\text { Myxoc } \\
\text { occus }\end{array}$ & $\begin{array}{c}\text { Average } \\
\text { strain } \\
\text { number of } \\
\text { Myxococc } \\
\text { us each } \\
\text { sample }\end{array}$ & $\begin{array}{c}\text { Strain } \\
\text { number } \\
\text { ofother } \\
\text { genera }\end{array}$ & $\begin{array}{c}\text { Average } \\
\text { strain } \\
\text { number } \\
\text { of other } \\
\text { genus } \\
\text { each } \\
\text { sample }\end{array}$ \\
\hline Yunna & 18 & 5 & 62 & 0.28 & 3.44 & 46 & 2.56 & 16 & 0.89 \\
\hline Hebei & 15 & 10 & 50 & 0.67 & 3.33 & 19 & 1.27 & 31 & 2.07 \\
\hline $\begin{array}{c}\text { Qinghai- } \\
\text { Tibet }\end{array}$ & 9 & 2 & 7 & 0.22 & 0.78 & 2 & 0.22 & 5 & 0.56 \\
\hline
\end{tabular}

Table 2. In vitro inhibition effect of ethanol extract from 48 Myxobacteria strains on L1210 and Hela cell lines

\begin{tabular}{|c|c|c|c|c|}
\hline \multirow{3}{*}{ Cell lines } & \multirow{2}{*}{ doses } & \multicolumn{3}{|c|}{ Number of strains with different inhibition rate } \\
\cline { 3 - 5 } & & $>30 \%$ & $>60 \%$ & $>90 \%$ \\
\hline \multirow{4}{*}{ L1210 } & $3.33 \mathrm{mg} / \mathrm{mL}$ & 4 & 0 & 0 \\
\cline { 2 - 5 } & $6.65 \mathrm{mg} / \mathrm{mL}$ & 13 & 0 & 0 \\
\cline { 2 - 5 } & $13.3 \mathrm{mg} / \mathrm{mL}$ & 30 & 14 & 0 \\
\cline { 2 - 5 } & $26.6 \mathrm{mg} / \mathrm{mL}$ & 43 & 36 & 6 \\
\hline \multirow{3}{*}{ Hela } & $3.33 \mathrm{mg} / \mathrm{mL}$ & 0 & 0 & 0 \\
\cline { 2 - 5 } & $6.65 \mathrm{mg} / \mathrm{mL}$ & 7 & 0 & 0 \\
\cline { 2 - 5 } & $13.3 \mathrm{mg} / \mathrm{mL}$ & 12 & 5 & 4 \\
\cline { 2 - 5 } & $26.6 \mathrm{mg} / \mathrm{mL}$ & 33 & 13 & 0 \\
\hline
\end{tabular}

Table 3. In vitro $\mathrm{IC}_{50}(\mathrm{mg} / \mathrm{mL})$ to $\mathrm{L} 1210$ and Hela cell lines of extracts from 7 Myxobacteria strains

\begin{tabular}{|c|c|c|c|c|c|c|c|}
\hline \multirow{2}{*}{ Cell lines } & \multicolumn{7}{|c|}{$\mathrm{IC}_{50}(\mathrm{mg} / \mathrm{mL})$ of different strains } \\
\cline { 2 - 8 } & $6 \#$ & $7 \#$ & $9 \#$ & $16 \#$ & $17 \#$ & $18 \#$ & $20 \#$ \\
\hline L1210 & 10.98 & 9.46 & 6.10 & 6.42 & 7.88 & 6.83 & 7.99 \\
\hline Hela & 11.35 & 9.47 & 16.99 & 7.34 & 8.34 & 11.60 & 8.41 \\
\hline
\end{tabular}

